Owen, A., Ebinghaus, A., Hartley, A. J., Santos, M. G.M. and Weissmann, G. S. (2017) Multi-scale classification of fluvial architecture: an example from the Palaeocene-Eocene Bighorn Basin, Wyoming. Sedimentology, 64(6), pp. 15721596.

There may be differences between this version and the published version. You are advised to consult the publisher's version if you wish to cite from it.

This is the peer reviewed version of the following article: Owen, A., Ebinghaus, A., Hartley, A. J., Santos, M. G.M. and Weissmann, G. S. (2017) Multi-scale classification of fluvial architecture: an example from the Palaeocene-Eocene Bighorn Basin, Wyoming. Sedimentology, 64(6), pp. 1572-1596, which has been published in final form at http://dx.doi.org/10.1111/sed.12364. This article may be used for non-commercial purposes in accordance with Wiley Terms and Conditions for Self-Archiving.

\title{
http://eprints.gla.ac.uk/144080/
}

Deposited on: 12 July 2017 


\section{Multi-scale classification of fluvial architecture: an example from the Palaeocene-Eocene Bighorn} Basin, Wyoming

Amanda Owen ${ }^{1}$, Alena Ebinghaus ${ }^{1}$, Adrian J. Hartley ${ }^{1}$, Maurício G.M. Santos ${ }^{2}$, Gary S. Weissmann ${ }^{3}$

${ }^{1}$ Geology and Petroleum Geology, School of Geosciences, University of Aberdeen, Aberdeen, UK.

${ }^{2}$ CECS, UFABC, Santo André, Brazil.

${ }^{3}$ Department of Earth and Planetary Sciences, University of New Mexico, Albuquerque, NM, USA.

Corresponding author email: a.owen@abdn.ac.uk Address: Department of Geology and Petroleum Geology, School of Geosciences, University of Aberdeen, Aberdeen, AB24 3UE, U.K.

\section{Abstract}

Fluvial channel geometry classification schemes are commonly restricted in relation to the scale at which the study took place, often due to outcrop limitations or need to conduct small-scale detailed studies. A number of classification schemes are present in the literature; however there is often limited consistency between them, making application difficult. The aim of this study is to address this key problem by describing channel body geometries across a depositional basin to ensure a wide range of architectures are documented. This was achieved by studying 28 locations over $4000 \mathrm{~m}$ of vertical succession in Palaeocene and Early-Eocene aged deposits within the Bighorn Basin, Wyoming, USA. Five different channel body geometries have been defined based on the external geometric form, and internal arrangement and nature of storey contacts. These include the Massive channel body body geometry, Semi-amalgamated channel body geometry, Internally amalgamated channel body sheet geometry, Offset stacked channel body geometry, which are considered to be subdivisions of the sheet geometry' of many other classifications. An Isolated channel body geometry has also been recognised alongside a channel and sheet sandstone geometries in the floodplain facies associations. Field evidence, including the stacking style of storey surfaces, suggests that the different geometries form a continuum. The nature and degree of amalgamation at the storey scale is important in producing the different geometries, and is related to degree of channel migration. It is speculated that this is the result of differences in sediment supply and available accommodation. In contrast to previous schemes, the classification scheme presented here recognises the importance of transitional geometries. This geometrical range has been recognised because of the basin-scale nature of the study.

\section{9 (1) Introduction}

Alluvial architecture assesses the lateral and vertical variations in grain size, geometry, and proportion of channel and floodplain deposits (Allen, 1978). Understanding variations in alluvial architecture has important economic implications as fluvial deposits are known to be economically important (i.e. petroleum, groundwater and mineral resources, $\mathrm{CO}_{2}$ sequestration). Understanding alluvial architecture also has important implications for palaeogeographic reconstructions. Key controls on alluvial architecture include intrinsic (i.e. avulsions, bar form migration, local sediment supply at the reach scale) and extrinsic processes (i.e. base level variations, tectonics and climate) (Bridge, 2008; Cecil, 2013). As these different processes can act at a range of scales and magnitudes, and are often interrelated, predicting the characteristics of alluvial architecture can be challenging. Indeed even effectively describing alluvial architecture can be challenging as it requires large scale, well exposed outcrops, 
and/or sufficient seismic data quality and coverage, and an abundance of closely-spaced borehole logs with sufficient dating to correlate between datasets (Bridge, 2008).

Alluvial architecture can be considered at a variety of scales, from the bedform, barform, storey, channel body, to system and finally to the basin scale (Fig. 1). Studies of alluvial architecture fall broadly into three main scales, those that consider the internal geometry of sandstone bodies, those that consider the external geometry of the sandstone bodies, which will be the focus of this study, and those that consider the stratigraphic architecture of alluvial deposits (i.e. the stacking arrangement of the channel bodies as addressed in the LAB model of Allen (1978), Leeder (1978) and Bridge and Leeder, (1979)), as is demonstrated in Figure 1. These different scales are bound by a series of hierarchal surfaces as described in Miall's $(1988,1996)$ architectural element analysis schemes, and demonstrated in Figure 1. This study focuses on the geometry at the channel belt scale and below (i.e. the channel body scale).

Gibling (2006) discussed a range of studies that present alluvial architecture schemes that concentrate on understanding the internal geometry and relationships of key surfaces and architectural elements within a channel body. Examples include the schemes of Jackson (1975), Allen (1983), Miall $(1985,1996)$ and Bridge (1993). The studies vary in terms of number of divisions present ranging from 3 (e.g. microforms, mesoforms and macroforms of Jackson, 1975) to 8 different divisions (e.g. bounding surfaces 1-8 of Miall, 1996), and generally vary in scale from the bedform to the channel body. However, as is argued by Bridge (1993) they can be difficult to use due to the complexity of the schemes, or may be oversimplifications in which important details are lost. Bridge (1993) also raises issues related to restricted timescales of the different orders, and the fact that schemes do not account for how surfaces may change order laterally. Despite the concerns raised by Bridge (1993), such schemes have been widely applied in a variety of fluvial studies (e.g. Miall, 1988; Singh et al., 1993; Miall, 1994; Corbeanu et al., 2001; Cain and Mountney, 2009; Leleu et al., 2009; Banham and Mountney, 2013; amongst others).

Gibling (2006) noted however that there are significantly fewer studies that comprehensively document the external geometry (i.e. the overall geometry of sandstone bodies in three-dimensions) and dimensions of fluvial deposits in the rock record. Examples of studies that consider and present schemes of the external geometry of sandstone bodies include Friend et al., (1979, Fig. 1), Blakey and Gubitosa, (1984, Fig 3), Hirst, (1991, Fig. 5), Gibling (2006, Fig. 4) Cain and Mountney (2009, Fig. 5), Huerta et al., (2011, Fig. 6), Pranter and Sommer (2011, Fig. 5), Gulliford et al., (2014, Fig. 5) and Owen et al., (2015a, Fig. 3). However, from the range of schemes presented, it is clear that no single scheme has received common acceptance, which may be the result of a lack of consistency related to differences in how different schemes have been created (either width:thickness ratio, facies, or stacking arrangement derived) or be related to differences in the range of scales at which studies have been conducted (outcrop to partial basin).

Width: thickness ratios (e.g. 15:1) have been used to differentiate different geometries in previous schemes, with further divisions being made based on 1) whether deposits are single or multistorey (e.g. Friend et al. 1979, Blakey and Gubitosa, 1984, Hirst, 1991, and Huerta et al. 2011), or 2) were deposited in confined and unconfined environments or form an amalgamated complex (e.g. Hirst, 1991). Huerta et al. (2011) further subdivided sheet and ribbon geometries based on the degree of interconnectivity and dominance of internal sedimentary features (accretions/bedforms). Pranter and Sommer (2011), used numerical data as part of their scheme with absolute lateral extent measurements placed on the 
based on whether they were single storey, multistorey or formed large amalgamated channel complexes. All other cited studies do not attach dimensions to their schemes, with Owen et al. (2015a) considering only end-member geometries (single and multistorey bodies), Gulliford et al. (2014) separating deposits at the sandstone body scale based on the nature of the stacking of channel belt elements, and Cain and Mountney (2009) differentiating units based on whether deposits are channelized or non-channelized elements, with further subdivisions based on facies present and whether the fluvial channels were laterally stable or not.

It is important to recognise that the various studies were conducted over different spatial scales. With the exception of Huerta et al., (2011), who studied a large portion of the Almazán Basin, Spain, the other studies are restricted aerially to either single outcrop belts (e.g. Pranter and Sommer, 2011; Gulliford et al., 2014), single depositional systems that are sourced from one catchment (e.g. Friend et al., 1979; Hirst, 1991; Cain and Mountney, 2009; Owen et al., 2015a), or focus on a particular area of a basin (e.g. Blakey and Gubitosa, 1984). The lack of consistency between the different studies and their general limited aerial extent indicate that a basin scale comprehensive study on channel body architecture is needed in order for channel body geometries from a range of systems (i.e. alluvial fan, distributive fluvial systems/megafans or axial fluvial system) to be accounted for. This study therefore aims to begin to address this problem by producing a classification scheme derived from a wide variety of fluvial systems (i.e. differently sourced systems, as depicted in Figure 1 ) developed across a single sedimentary basin.

\section{(2) Aims and methods}

This study focuses on documenting the internal and external geometries of channel bodies present within the Palaeogene aged Fort Union and Willwood Formations of the Bighorn Basin, Wyoming (Fig. 2). Both Formations were studied, as paleocurrent maps presented by Seeland (1998) showed them to be composed of the same genetic fluvial systems. Channel bodies are defined as a single, interconnected mappable body of channel deposits - a definition modified from that of Potter (1967)(see Gibling, 2006 of the basin fill, ensuring that this study can capture a wide range of fluvial architectures.

Sedimentological data in the form of sedimentary logs were collected that cover an area of 8,700 $\mathrm{km}^{2}$, and a total of 4,192 $\mathrm{m}$ of vertical succession, alongside architectural panels of the studied outcrops. A total of 184 channel deposits were studied from 28 locations (Fig. 2), 12 from the Palaeocene Fort Union Formation, 16 from the Eocene Willwood Formation,. Facies associations were depicted from sedimentary log data in order to interpret depositional environments present. As is highlighted by Bridge (1993, p.809) 'The geometry of an individual channel belt depends on the geometry of channel(s), the mode of migration of the channels(s) within the channel belt and the rate of deposition or erosion'. In order to capture these key processes, geometries within this study were defined based on their internal characteristics (i.e. facies present, number of stories present and nature of internal contacts) and external form to ensure that characteristics such as the mode of channel belt migration and internal processes were documented. Storey surfaces are defiend in this paper to be erosional elements of the active portion of a channel base, which incise into previous channel deposits, as is shown in Figure 1. Storey surfaces therefore have associated bars and channel -fill deposits that filled that particular incision event. These can either scale to one channel-fill (bar), or be associated with multiple stacked bars. Widths cited in this paper are taken perpendicular to palaeocurrent flow. 


\section{(2) Tectonic Framework and Basin Extent}

126 The Bighorn Basin is situated in north-west Wyoming and south-central Montana (Fig. 2). It is a broadly NNW-SSE trending intermontane foreland basin that is $200 \mathrm{~km}$ long and $80 \mathrm{~km}$ wide (Willis and Behrensmeyer, 1995). The present basin margin is defined by the presence of several Laramide-age basement-cored uplifts (the Beartooth Mountains to the northwest, the Owl Creek Mountains to the south and the Bighorn Mountains to the east, Fig. 2), which formed as a result of the segmentation of the Late Jurassic to Cretaceous foreland basin of the western US due to a switch from thin- to thickskinned deformation (Snyder et al., 1976; Dickinson et al., 1988; Decelles, 2004). The Pryor Mountains situated in the northern part of the basin close to the Wyoming-Montana border (Fig. 2) are also Laramide-age structures but are not thought to have been a continuous topographic barrier during the Palaeocene and Eocene (Kraus and Hasiotis, 2006). The southwestern part of the basin is currently largely overlain by the Absaroka Mountains (Fig. 2) which are composed of mid- to late-Eocene volcanic rocks (Rouse, 1937) and post-date deposition of the Fort Union and Willwood Formations. Several studies speculate the location of the southwestern margin of the Palaeocene-Eocene to be the Washakie Range (located approximately $30 \mathrm{~km}$ NE of Dubois, Wyoming), or the Cody Arch (Fig.2) (e.g. Kraus, 1985; Sundell, 1990; Lillegraven, 2009).

\section{1 (2) Fort Union and Willwood Formations}

142 The Fort Union and Willwood Formations were deposited in the Bighorn Basin during the Palaeocene and Eocene. A broad change in colour distinguishes the two formations, with the Fort Union Formation dominated by drab-grey palaeosols and the Willwood by lighter coloured red palaeosols (Willis and Behrensmeyer, 1995). The colour change has been attributed to either improved drainage as a result of reduced subsidence rates and continued high sedimentation rates (Gingerich, 1983), or due to a regional change to warmer and drier conditions (Willis and Behrensmeyer, 1995; and references within). A short lived (200,000 year), but abrupt warming $\left(\sim 5^{\circ} \mathrm{C}\right)$ occurred at the end of the Palaeocene, known as the Palaeocene-Eocene Thermal Maximum (PETM) (Kennett and Stott, 1991; Kraus et al., 2015). This is recorded close to the boundary between the Fort Union and Willwood Formations, and has been extensively studied within the basin (e.g. Gingerich, 2003; Wing et al., 2005; Kraus and Riggins, 2007; Kraus et al., 2013; Wing and Currano, 2013; Foreman, 2014; Kraus et al., 2015).

The Palaeocene Fort Union Formation was deposited in a range of alluvial environments including alluvial fan, fluvial channels (braid plain and meandering), floodplain (e.g Kraus, 1985; Willis and Behrensmeyer, 1995; DeCelles et al., 1991 Seeland, 1998; Kraus and Hasiotis, 2006), and minor lacustrine deposits (e.g. Yuretich et al., 1984; Hickey and Yuretich, 1997). Palaeocurrent patterns from Seeland (1998), indicate rivers during the Palaeocene were flowing in a broadly north-east direction.

Deposits from the Willwood Formation also represent deposition from a suite of alluvial environments. Davies-Vollum and Kraus (2001), describe the Willwood Formation as mud-dominated with channel deposits representing deposition from sinuous rivers. Coarser grained deposits are intermittently present in the west which are interpreted to have been deposited in braid plains (Neasham and Vondra, 1972; Kraus, 1985). As a result of the excellent exposure of the floodplain deposits a suite of studies have focused on documenting the palaeosols of the Willwood Formation (e.g. Bown and Kraus, 1981; Bown and Kraus, 1987; Kraus, 1987; Kraus and Bown, 1993). 
Despite the wide range of studies conducted on the Fort Union and Willwood Formations, only limited work has focussed on describing the range of fluvial architectures present. Foreman (2014) (expanding on the work of Kraus, 1980), presents the most detailed study on the internal architecture of channel deposits, documenting the highly amalgamated nature of a sandstone complex that coincides with the PETM. DeCelles et al. (1991) document the detailed internal architecture of the conglomerate deposits in the northwest of the basin establishing seven orders of bounding surfaces within alluvial fan and braid plain deposits. Kraus (1985) describes the internal structures found in conglomerates in the southwest portion of the basin. Other studies have concentrated on documenting the fills of predominately mudfilled avulsion deposits (e.g. Kraus, 1996; Kraus and Wells, 1999; Davies-Vollum and Kraus, 2001; Kraus and Davies-Vollum, 2004), or present generic basin-scale alluvial architectural panels where channel deposits are shown in relation to floodplain deposits (e.g. Fig. 3A of Kraus and Gwinn, 1997 and Fig. 2 of Kraus, 2001). However, these studies are either of a limited aerial extent within the basin, or have concentrated on a select few outcrops. The studies do, however, highlight that a range of alluvial architectures are present within the basin-fill, and therefore there is suitable scope to present a basin scale study of fluvial architecture.

\section{(1) Facies association description}

Two broad facies associations, fluvial channel and floodplain, have been identified.

\section{(2) Channel Facies Association}

Facies association descriptions in this section are concerned with describing sediments from the grain scale up to, but not including, the storey scale (i.e. grain scale, bedform and barform scale, see Fig. 1). Descriptions at the storey scale and above (i.e. the nature and cross-cutting relationships of stories) are considered in the geometry section.

\section{(3) FA1 - Gravelly braided stream}

FA1 comprises conglomerates ranging from granule to boulder grade material with pebble to cobble sized clasts predominating (Fig. 3A). The majority of clasts are very well-rounded quartzite and are sometimes imbricated when a long axis is visible (Fig. $3 A$ ). Deposits are normally clast supported and moderately sorted, but can on occasion be poorly sorted (Fig. 3A). Fining and coarsening up sequences are often present over a 1-5 m scale. The matrix is composed of silt to coarse sand-sized grains. Thin (0.5-4.3 m) wedge shaped sandstone packages can be present, but are not laterally extensive $(<25 \mathrm{~m}$ wide) (Fig. 3C), and maybe internally structureless or display trough cross-bedding with a depositional rather than erosional contact. Foresets (up to $4 \mathrm{~m}$ in height) which predominately dip in a downstream direction, can on occasion be observed with lateral accretion surfaces only rarely identified. Horizontal stratification can also on occasion be observed (Fig. 3B, C), making the deposits largely massive with respect to the presence of bedforms and barforms

The largely massive nature of the deposits coupled with the presence of horizontal stratification and minor presence of downstream accretion surfaces suggests bedload-sheet deposition, that in places are indicative of longitudinal gravel bars through the presence of horizontal stratification and downstream accretion surfaces (Rust, 1972). The wedge shaped sandstone packages are interpreted to represent waning flow deposits on top of bar surfaces, on the channel floor, and/or accretion surfaces (Rust, 1972; Ramos and Sopena, 1983). Kraus (1985) and DeCelles et al., (1991) describe similar deposits in the 
Bighorn Basin and infer a braided depositional environment. Observations made in this study concur with such interpretations as deposition from gravel sheets and dominance of downstream accretion (when it can be observed) and a generally low spread in palaeocurrent direction (Fig. 3A) are more diagnostic of braided environments (Bristow and Best, 1993) and largely absent from meandering 209 systems.

\section{0 (3) FA2 - Heterolithic, dominantly braided}

211 FA2 includes a range of grain sizes from medium sandstone to cobble sized clasts with sandstone 212 forming approximately $30 \%$ of the facies association and conglomerate $70 \%$. Sedimentary structures such as horizontal lamination and trough cross-bedding are more commonly observed in FA2 in comparison to FA1, with sets rarely reaching $1 \mathrm{~m}$ in thickness. Granule sized grains often line trough cross-laminae surfaces (Fig. 4A). Conglomerate deposits in the north-west of the basin are generally more rounded and better sorted than those in the south-west where clasts are more angular and matrix supported (Fig. 4B). Accretion surfaces are more prevalent than in FA1, with downstream accretion surfaces, up to a maximum of $6 \mathrm{~m}$ in thickness, being more prevalent than lateral accretion surfaces (Fig. $4 \mathrm{C})$.

The presence of bedforms and barforms throughout the deposits suggests more sustained flow conditions, in which sediment load may have been reduced in comparison to FA1, allowing bedforms to develop. The deposits are regarded to be from mixed braided-meandering planform (i.e. a wandering planform), with the former dominating as is indicated by the dominance of downstream relative to lateral accretion surfaces and relatively low spread in paleocurrent directions (Fig. 4C). The mixture of the two grainsizes (Fig. 4) suggests deposition either in proximal environments where textural sorting is not yet achieved, or that a flashy discharge regime was present .

\section{7 (3) FA3 - Heterolithic dominantly meandering}

The deposits of FA3 are composed predominantly of fine to medium sand, but can range from silt to coarse sand. Granules, carbonate nodules and mudclasts may line trough cross-sets, accretion surfaces, and form lags at the base of storey surfaces (Fig 5A). Mud may also be present as part of heterolithic accretion packages (Fig. 5B) or as scour fills. The sediments are generally well sorted, with grains ranging from sub-angular to sub-rounded. Trough cross-bedding is the dominant structure (Fig. 5A, C) with upper-plane-bed lamination also common. Current ripples, lower plane bedding, and soft sediment deformation (Fig. 5D) form minor constituents of the deposits. Thin, organic-rich layers containing fossil leaves may be present at the base of channels, or line accretion surfaces, but such deposits are only found associated with poorly drained sequences (see palaeosol descriptions). Lateral accretion is more prevalent than downstream accretion, and accretion packages can either be heterolithic or composed entirely of sand. FA3 is predominantly composed of multiple bar deposits (Fig. 5B), but channel fills in which only a single bar deposit (which can reach thickness of $6 \mathrm{~m}$ ) can on occasion be observed.

The moderate sorting of material suggests deposition from relatively perennial flow conditions, with the presence of coarser grains, mud clasts and carbonate nodules on cross-sets indicating fluctuations in discharge. The prevalence of lateral accretion which is found alongside downstream accretion suggests a wandering planform in which a meandering form prevailed, but also contained braided features (i.e. mid-channel bars). A higher spread in paleocurrent data supports this interpretation, as can be seen in Figure 5B. Sand-dominated channel deposits have also been recognised in the basin by other authors, 
such as Kraus, (1987), Willis and Behrensmeyer (1995), Kraus (1996), Kraus and Wells (1999), Kraus (2001), Jones and Hajek (2007), and Foreman (2014).

\section{(3) FA4 - Fine grained channel fill}

The grain size of facies association FA4 ranges from silt to medium sand. Current ripples and trough cross-bedding can be found in sand grade material, while horizontal lamination can be observed in both mud and sand grade beds. The deposits of FA4 are relatively simple in nature. Accretion surfaces are very rare, while multiple small scale $(<1 \mathrm{~m})$ horizontal beds (Fig. $6 \mathrm{~A})$, that can either be heterolithic in nature or entirely composed of mudstones (Fig. 6B), are common. Pedogenic modification (rootlets and mottling) can on occasion be observed.

It is hypothesised that the mud-dominated channels are either abandoned channel fills (e.g. Hornung and Aigner, 1999; Kraus and Davies-Vollum, 2004), or were groundwater fed channels (e.g. Singh et al., 1993). In the case of the heterolithic bedded fills, the channels are interpreted to have been deposited from rivers with intermittent, lower discharges, possibly in distributary channels or proximal splay environments (Banham and Mountney, 2013).

\section{(2) Floodplain Facies Associations}

Due to the extensive exposure of floodplain deposits in the Bighorn Basin there have been numerous studies that document their characteristics (e.g. Bown and Kraus, 1981; Yuretich et al., 1984; Bown and Kraus, 1987; Kraus, 1987; Kraus and Bown, 1993; Hickey and Yuretich, 1997; Kraus and Gwinn, 1997; Davies-vollum and Wing, 1998; Kraus and Hasiotis, 2006; Abdul et al., 2008; Abels et al., 2013). As this paper focuses on channel deposits in the basin, floodplain characteristics are only briefly described. Three elements were recognised: lacustrine, palaeosol, and splay deposits.

\section{(3) FA5 - Lacustrine}

Lacustrine deposits were only documented in the northern portion of the basin at location 14 (Fig. 2). Deposits can either be mud- or sand-dominated, contain horizontal stratification (Fig. 7A) and bioturbation, with trough cross-bedding $(<50 \mathrm{~cm})$ and current ripple lamination forming only minor constituents of the beds when sand fractions dominate. The sandstone deposits have sharp bases and have a tabular form (Fig. 7B). Mudstone deposits are clay to silt grade, have a drab grey colouration and are horizontally laminated (Fig. 7A). Only one limestone bed was measured in the basin in this study but this lithology has been documented by Yuretich et al. (1984) and Hickey and Yuretich (1997) in the northern portion of the basin. The limestone bed was composed of lime mud, where faint wavy to horizontal lamination and one gastropod were observed. The lacustrine deposits are often closely associated with thin ( $<50 \mathrm{~cm}$ thick) beds of coals (Fig. 7B). The lacustrine deposits are not considered to have been deposited in large lakes, but rather from shallow, aerially restricted lakes that were likely subtle topographic depressions on the floodplain (Yuretich et al., 1984; Hickey and Yuretich, 1997).

\section{(3) FA6 - Palaeosols}

Palaeosol deposits have received a considerable amount of attention in the Bighorn Basin, particularly with regards to the Palaeocene Eocene Thermal Maximum (e.g. Kraus et al., 2015). Comprehensive descriptions of palaeosols present within the basin include Bown and Kraus (1981), Bown and Kraus (1987), Kraus (1987), Kraus and Bown (1993), Kraus (1999), Kraus and Hasiotis (2006), Kraus and Riggins 
(2007), and Kraus et al. (2015). Two broad types of palaeosols are defined across the entire basin namely moderate to well-drained palaeosols and poorly-drained palaeosols.

The moderate to well-drained palaeosols range in grain size from clay to fine-medium sand, with sandy silt dominating. Individual rootlets, rhizoliths, carbonate nodules, slickensides, mottling (purple, orange, and red), organic matter, and bioturbation are all observed to varying degrees in the well-drained palaeosol sequences, while primary features are very rarely observed (Fig. 7C, D). The well-drained palaeosols are generally moderately to well-formed cumulative soils and are various shades of red in colour (Fig. 7C), indicating oxidation of the soils (Retallack, 2001). The well-drained palaeosols are most dominant in the Willwood Formation, but do also occur in the Fort Union Formation.

Poorly-drained palaeosols also range from clay to fine-medium sand in grain size, with sandy-silt grain sizes dominating. The poorly-drained palaeosols also contain rootles, slickensides, mottling (orange, purple, and red), and burrows but to a lesser degree than that of the well-drained palaeosols with the exception of organic matter which is more prevalent in the poorly-drained facies. In addition, yellowbrown accumulations are also observed, and represent goethite deposits (Kraus and Hasiotis, 2006). The poorly-drained soils are less mature than the well-drained soils, and possess a grey, dark grey, greengrey, and purple colouration (Fig. 7D). These characteristics suggest the soils were relatively saturated, which could either be due to high water tables, or due to the characteristics of the soil hindering drainage (i.e. grain size) (Kraus, 1999). Thin, organic rich carbonaceous layers and thin coals $(<1 \mathrm{~m})$ are associated with the poorly drained soils, but are relatively uncommon across the basin. Poorly drained soils are present across the basin, but are more prevalent in the Fort Union Formation on the periphery of the basin, and in the northern portion in the basin centre.

\section{(3) FA7 - Splay and sheet flood deposits}

Sheet and ribbon sandstone deposits form common constituents of floodplain material in the Bighorn Basin. The grain size ranges from very fine sand to coarse sand in sheet sandstones, with sediments generally well sorted with floating granules rarely present. Horizontal lamination, ripple lamination and trough cross-bedding are all present. Vertical, horizontal, and sub-horizontal burrows are observed to varying degrees. The sheet sandstones are interpreted to represent unconfined flow conditions on the floodplain, either as part of a splay complex (terminal or lateral e.g. Fisher et al., 2007), or may have formed from overtopping of the banks of the channel (e.g. Shen et al., 2015).

The ribbon sandstones (as defined by Friend, 1983) are composed of a single fill of trough cross-bedding, ripple lamination and horizontal lamination, and do not contain any bars. Based on their internal characteristics and intercalative relationship with sheet sandstones and paleosols, these channels are interpreted to be the channelized portion of splay deposits, and have also been noted in previous studies (e.g. Kraus, 1987; Kraus, 1996b; Kraus and Wells, 1999; and Kraus and Davies-Vollum, 2004).

\section{(1) Sandstone body geometries}

Seven sandstone body geometries are defined within this study; five of which are associated with channel facies, which is the focus of this study, and two of which are associated with floodplain facies (Fig. 8). The five channel geometries are defined based on overall geometric shape and internal relationship of storey surfaces. Here the geometries present are described, with potential controls on 
the different geometries presented in the discussion section. Summary information can be found in Table 1.

\section{(2) M - Massive channel body geometry}

The massive channel body geometry has a wide range of thicknesses measured $(n=8)$, ranging in thickness from $5.7-47.5 \mathrm{~m}$ (Fig. 9). Due to its large size, full lateral extents cannot often be measured; however at Location 16 (Fig. 2, Fig. 10A), a lateral extent of $5.5 \mathrm{~km}$ was observed. The deposits pinch out laterally into floodplain material, defining a large, broad channel geometry. Minimum lateral extents did not exceed $1.5 \mathrm{~km}$, however these measurements were the result of exposure limitations. There is commonly little relief on the basal incision surface (up to $3 \mathrm{~m}$ ) when compared to the size of the bodies (up to $47.5 \mathrm{~m}$ ), with both convex and concave geometries observed (Fig. 8A, Fig. 10A)

Internally, the deposits are considered to be massive with respect to the lack of apparent storey surfaces present, which is a defining internal feature of this geometry. Storey surfaces are rare, but when present up to five storey surfaces can be observed (average of 2.1 stories present), which have thicknesses ranging from $1.4-47.5 \mathrm{~m}$ (average of $10.1 \mathrm{~m}$ ). Storey surfaces have limited lateral (up to $200 \mathrm{~m}$ ) and vertical relief $(2 \mathrm{~m})$, and therefore do not appropriately scale to the size of the channel body (Fig. 10A). The storey surfaces do not cross-cut one another and transition into sediments laterally ('transitional surface' in Fig. 8A). It is speculated that the coarse grain size makes identifying storey surfaces difficult, and it is therefore not ruled out that many more may be present. $M$ can be composed of FA1 and FA2 and is considered to be similar to the sheet-like channel bodies with high interconnectivity of Huerta et al. (2011). It can be inferred that geometry M can be applied to some of the deposits previously described within the basin by Kraus, (1985) and Decelles (1991) based on images and descriptions within the texts.

\section{(2) SA - Semi-amalgamated channel body geometry}

The semi-amalgamated channel body geometry (SA) has an external geometry in which broad sheet-like bodies are semi-amalgamated, with up to $50 \%$ of the channel belt base in contact with floodplain deposits and the remainder with a channel deposit on channel deposit contact (i.e. transitions into a storey surface) (see Fig. 8B for diagrammatic explanation, Fig. 10B for example). This results in a semiamalgamated irregular external form which has pockets of floodplain material that locally separate channel deposits along the margins of the body (Fig. 8B, Fig. 10B). Paleocurrent directions were found to be relatively consistent between the amalgamating portions, supporting the notion that the amalgamation is not a local feature, indicating that a complex three-dimensional geometry is present. As with $\mathrm{M}$, the extremities of the deposits were only rarely observed and when done so the deposits pinch out laterally into floodplain deposits. Channel bodies with a SA geometry range in thickness from $1-$ $44.5 \mathrm{~m}(\mathrm{~N}=42$ ) (Fig. 9), with an average of $7.5 \mathrm{~m}$ calculated, with the largest minimum lateral extent measured as being $3.5 \mathrm{~km}$.

Internally, storey surfaces are more prevalent than in geometry M. Storey surfaces can be both spatially isolated from one-another, or can cross-cut one another (Fig. 8B, Fig. 10B). SA is considered to be predominantly multistorey with up to three storey surfaces identified (average of 1.3 stories present, Table1) within a single SA body. Individual story packages range in thickness from 1- $30.3 \mathrm{~m}$ (average thickness $5.7 \mathrm{~m}$ ), although again issues with exposure quality in the latter may be yielding apparent thicknesses. Geometry SA can be composed of FA1, FA2 and FA3. It is considered to be geometrically 
similar to complex type B of Gulliford et al., (2014). As with geometry M, it can be inferred from descriptions and images within Kraus, (1985) and Decelles (1991) that Geometry SA can be allocated to some of the deposits described within the recognised studies texts.

\section{(2) IA - Internally amalgamated channel sheet geometry}

Geometry IA has a simpler form than SA with a broadly sheet-like form (Fig. 8C, Fig. 10C) that extends laterally for up to $3 \mathrm{~km}$ 's in Willwood exposures, however it is suspected this is a minimum due to outcrop limitation. The channel geometry is simpler and more uniform in nature than that of SA (Fig. 9). When visible the deposits pass laterally into floodplain deposits in a gradational manner, but on occasion a steep cut bank can be observed. IA ranges in thickness from $4.1 \mathrm{~m}$ to $27.6 \mathrm{~m}(\mathrm{~N}=46)$ (Fig. 9), with an average of $11 \mathrm{~m}$ calculated.

Internally, IA generally has the most abundant storey surfaces present of all the geometries described (average of 2.4 stories, Table 1) IA is multi-storey with 2 to 4 stories present (Fig. 10D). Storey surfaces can be laterally extensive (up to $300 \mathrm{~m}$ measured) but are most commonly truncated laterally and vertically by other storey surfaces (Fig. 8C, Fig. 10D). Transitional storey surfaces, where storey surfaces laterally taper out and become indistinguishable, are on occasion observed ('transitional storey' in Fig. 8C). Storey packages are on average $4.6 \mathrm{~m}$ thick, ranging from $1.5 \mathrm{~m}$ to $14.3 \mathrm{~m}$. IA can be composed of FA2, but more commonly FA3 and FA4. IA is recognised in many schemes including the multistorey sheet of Blakey and Gubitosa (1984), multistorey/multilateral and amalgamated complex of Hirst (1991) and Pranter and Sommer (2011), the amalgamated channel-fill complex of Cain and Mountney (2009), the intermediate sheet-like bodies of (Huerta et al., 2011), and the amalgamated channel belt of Owen et al. (2015a). Geometry IA has been recognised as sheet sandbodies in other studies conducted in the Bighorn Basin such as Kraus and Middleton (1987), Kraus (1996), Davies-Vollum and Kraus (2001), Kraus and Davies-Vollum (2004) and Foreman (2014).

\section{(2) OS - Offset stacked channel body geometry}

The internal arrangement of storey surfaces distinguishes geometry OS from IA. In OS, storey packages are juxtaposed onto one another in an offset manner laterally and vertically, resulting in some surfaces being in contact with underlying channel deposits, and others in contact with underlying floodplain deposits (Fig. 8D). In this respect, OS can be either single storey or multistorey depending on where it is defined (Fig. 11A), with 1 to 3 stories present (average of 2 stories present, Table 1), that range in thickness from 0.3 to $7.1 \mathrm{~m}$ (average of $3.8 \mathrm{~m}$ ). This results in a complex irregular external sheet like geometry (Fig. 8D, Fig. 11B). Internally the deposits are composed of offset stacked channel-fill deposits with only partial vertical juxtaposition, resulting in limited lateral and vertical connectivity and high spatial variability in thicknesses across channel bodies (Fig. 8D, Fig. 11A). The minor but important vertical juxtaposition can result in a subtle climbing trajectory of the deposits. Offset stacked sheet sandstones range in thickness from $2.4 \mathrm{~m}$, when measured at a point in which only a single storey is present, to $13.7 \mathrm{~m}$ in thickness when several stories are amalgamated (average of $7.7 \mathrm{~m}$ calculated, $\mathrm{N}=12$ ) (Fig. 9). When compared to $\mathrm{M}, \mathrm{SA}$ and IA, OS has a relatively narrower range in thicknesses (Fig. 9). Exposure limitations meant that a maximum lateral extent could not be obtained, however the largest lateral extent measured was $1 \mathrm{~km}$. OS can be composed of FA3 and FA4. To the authors knowledge this geometry has not been previously documented in the Bighorn Basin, and has only been previously recognised in Gulliford et al. (2014) as their complex type A. 


\section{(2) I - Isolated channel body geometry}

407 The isolated channel body geometry (I) is single storey, with no internal storey surfaces present (Fig. 8E) 408 and is composed of FA3 and FA4. I is considered to possess a simple 'classic' external channel geometry, 409 which can either be asymmetric when only a steep cut bank is observed on one side (Fig. 11C), or 410 symmetric when it is observed on both sides of the channel body (Fig. 8E). Channel bodies do not extend 411 laterally for more than $1 \mathrm{~km}$, and has the smallest range in thicknesses of the geometries, ranging from $4121.7 \mathrm{~m}$ to $11.4 \mathrm{~m}$ (average of $4.2 \mathrm{~m}$ calculated, $\mathrm{N}=76$ ) (Fig. 9). The isolated channel body geometry is 413 recognised in all cited schemes (Friend et al., 1979; Blakey and Gubitosa, 1984; Hirst, 1991; Cain and 414 Mountney, 2009; Huerta et al., 2011; Pranter and Sommer 2011; Gulliford et al., 2014; and Owen et al., 415 2015a), but may be reffered to as ribbon, fixed or single storey channel bodies (i.e. width-to-thickness 416 aspect ratio of 15:1, Friend et al., 1979). It has also been regonised as ribbon geometries in Kraus and 417 Middleton (1987), Kraus, (1996), Davies-Vollum and Kraus (2001)and Kraus and Davies-Vollum (2004).

\section{8 (2) Floodplain sandstone geometries}

419 Two sandstone geometries were observed within the floodplain facies association; sheet (FS) and ribbon channel (FR). Sheet sandstones generally have a tabular form with sharp bases (Fig. 7D, 8F), but undulating forms are also present. When observed, sheets pinch-out laterally over large distances (up to $1 \mathrm{~km}$ observed), and do not exceed more than $2 \mathrm{~m}$ in thickness. This results in the sheets possessing a very broad concave-down geometry. Ribbon sandstones range in thickness from 0.2 to $3.4 \mathrm{~m}$ (Fig. 7E, 8G) (1.2 $\mathrm{m}$ average), are not laterally extensive ( $<150 \mathrm{~m}$ wide), and possess a similar geometric form to the channel geometry I.

\section{(1) Discussion}

A sandstone body geometry scheme has been presented based on a basin wide study from the Bighorn Basin, Wyoming. A total of seven different sandstone geometries have been defined from channel and floodplain facies. To the authors' knowledge this is the first study to document a suite of channel geometries across a near entire depositional basin. As a result, a wider array of channel body architectures has been captured in comparison to previous studies within the Bighorn Basin and beyond, which are summarised in Figure 8. It is recognised that Gibling (2006) complied a scheme from a large literature based dataset, however our study is able to put the described sandstone geometries in context of one another as well as describe key internal characteristics (facies present and storey surface characteristics) to help devise the scheme. It is considered that the scheme presented in this paper has subdivided the 'sandstone sheet' geometry used in many classification schemes (e.g. Friend et al. 1979) into 4 distinct geometries ( $\mathrm{M}, \mathrm{SA}, \mathrm{IA}, \mathrm{OS}$ ) based on the internal arrangement and nature of storey surfaces which reflect processes that formed the sandstone bodies rather than just width: thickness data being the diagnostic feature. Other studies such as Hirst (1991) do recognise the multistorey nature of described sheet sandstones, which has now been built upon. The ribbon geometry has also been recognised (I) as well as two sandstone body geometries (FS and FR) within the floodplain facies association.

444 A key defining feature of the different sandstone geometry types in Figure 8 is the nature and stacking 445 style of the storey packages. There is also an apparent relationship with regards to sandstone geometry 
and facies associations present (i.e. grain size and sorting, nature of bar deposits), with certain facies associations only being found within certain sandstone body geometries. These factors therefore may give potential insights into what the key controls on determining the different sandstone body geometries are. Traditional models that assess fluvial architecture, such as the LAB model (of Leeder, 1978, Allen, 1978, and Bridge and Leeder, 1979), consider amongst other things such as compaction, and tectonic movement on floodplain margins, that sedimentation rate, aggradation rate and channel belt avulsion frequency have a profound effect on the formation of different fluvial stacking styles. From a simple perspective, when all other parameters are considered constant, reduced sedimentation rates result in a high stacking frequency of channel deposits, and high sedimentation rates result in a low stacking frequency of channel deposits (e.g. Bridge and Leeder, 1979). Whilst most studies that take this approach are largely focussed at the stratigraphic architecture scale (see Fig. 1), the same principles can be applied at the storey scale when considering the stacking arrangement of storey packages. This study therefore considers processes that occur over approximately a $10^{0}-10^{4}$ years scale (after Miall, 2016). Each of the channel body geometries identified here are discussed in this context such that a comparison can be drawn between them.

Internally, geometry $\mathrm{M}$ possesses a limited amount of storey surfaces that do not cross-cut one another, which have minimum lateral extents (200 m max) and erosional relief ( $2 \mathrm{~m}$ ) (Table 1, fig. 8). Their limited lateral extent is interpreted to represent either; 1 ) brief incision phases that were not sustained in strength or time; or 2) indicate that there was insufficient grain size contrast to distinguish further surfaces. If the former interpretation is correct, then this suggests minimal deposit reworking which is consequence of high aggradation and sedimentation rates or static discharges. Evidence for high sediment supply and storage can be seen by the dominance of FA1 and FA2 in geometry M which are interpreted as gravel braid sheets. However, if it is inferred that more storey surfaces are present, a low accommodation to sediment supply regime can be considered, in which the channels were highly mobile, which the braided interpretation with a coarse grain and limited low relief barform presence would support.

Geometry SA has a higher abundance and larger lateral extent of storey surfaces relative to geometry M suggesting higher rates of channel migration and reworking. A higher dominance of FA2 (better sorting and reduced grain size), suggests a reduced sediment supply in comparison to M. However, SA is still considered to have a relatively high sediment load, as indicated by the poorly sorted nature (indicating relatively proximal locations where sediment supply is deemed to be highest), the subdued nature of the bedforms and barforms, and presence of FA1 and 2 with intercalations of FA3. Geometry SA reflects an aggradation rate that is not sufficient enough toelevate subsequent channel deposits above the floodplain, with basal storey surfaces removing floodplain material resulting in juxtaposition against underlying channel body deposits. The preservation of some floodplain (that separates channels in some areas), is deemed to be due to incision not being extensive across the channel belt area. This results in an irregular geometry in which minor, non-continuous floodplain remnants are preserved (Fig. 8B, 10B). by the cross-cutting nature, abundance of, and more continuous extent of, storey surfaces. However key differences between geometry IA and SA are the more distinctive tabular form of IA and lack of floodplain intercalations. A lack of floodplain intercalations suggests two scenarios with respect to aggradation rates: 1) following channel avulsion floodplain aggradation was sufficient to separate and define the distinctive IA sheet geometry rather than amalgamate to form a SA geometry or, 2) the rate 
of reworking was too high to allow floodplain deposits to be preserved. The dominance of FA3 and FA4 suggests there was reduced sedimentation in comparison to $M$ and $S A$, as bedforms and barforms are more abundant and pronounced, and sediment is generally better sorted (Collinson, 1996). The intermittent presence of FA2 does suggest a fluctuating discharge. These factors favour scenario 1 in which relatively high floodplain aggradation rates were present as the decrease in lateral extents, thickness and storey height relative to geometry SA (Table 1) implies the channels were smaller in size such that it is difficult to envisage such small scale channels creating such large scale reworking The channels are considered to have been deposited from a sinuous planform, as is suggested by the dominance of FA3 and 4 in which lateral accretion deposits dominate. Storeys are observed to either systematically migrate across the channel belt, as shown by the lateral migration of storey packages, or occur randomly juxtaposed onto previous deposits with little evidence for lateral migration of the channel belt, possibly resulting from intra-channel belt avulsion of the active channel.

A relative difference in aggradation rate is also considered to have produced geometry OS. Higher aggradation rates resulted in an important lateral and vertical migration of the channel where the channel 'steps' along the landscape in a subtle climbing trajectory (as depicted in fig. 8D), or when elevation of the floodplain is sufficient for channel emplacement (avulsion) to occur in a random manner. This results in a lower degree of amalgamation of storey packages in geometry OS relative to IA, with storey packages only partially amalgamating with one another to produce an irregular tabular body at a larger scale (fig. 11B). Geometry I shows no evidence for reworking at the storey scale as no storey surfaces are defined. This indicates that the river was relatively fixed in position, and that there was channel migration through avulsion in a setting in which there was ample aggradation and space for it to do so and not juxtapose onto previous deposits. The dominance of FA4 and moderate identification of FA3 for geometry I implies reduced sedimentation rates as indicated by the better sorting of sediment (Collinson, 1996) and clearly defined bar features and bedforms in comparison to all other geometries.

It is therefore considered that a combination of degree of channel migration, aggradation rate and sediment load to vary between the described geometries and to form the key controls on geometry development. Such controls have also been noted by Bristow and Best (1993) to be key in the preservation of braided morphology (Fig. 5 of Bristow and Best, 1993) and also in Figure 15 of Gibling (2006). The relative differences between the different geometries could be the result of changes in the accommodation and sediment supply regime through time. The changes in sediment supply and accommodation can occur over two different scales; at the longer allogenic or shorter autocyclic scale. However as discussed by Cecil (2003) these two scales can overlap. Large scale regional and detailed mapping is needed to capture both scales, as has been done in on fluvial systems studied by Rittersbacher et al., (2014) and Owen et al., (2015b). Autocyclic changes are deemed to be relatively local in nature resulting in minor discontinuities (Miall, 2016). Unless surfaces are able to be mapped regionally, which the cases described in here were not able to be, it is deemed that the storey surfaces and subsequent fills were largely under the autocyclic scale control (e.g. local storage and release of sediment, seasonal fluctuations in discharge). However, longer term allocyclic controls (i.e. tectonics and climate) will also have an overriding background influence on this (i.e. sediment delivery to basin which can be controlled by climate and tectonics, Cecil, 2003). Longer term controls will eventually lead to the different stacking patterns of the storey surfaces seen in the different geometries. The different geometries can therefore provide information on the local variations in accommodation and sediment supply. It is speculated that the repeated stacking of certain geometries will help infer allocyclic trends. 
For example, a high accommodation and low sediment supply regimes may be dominated by geometries OS and I, while a low accommodation and relatively high sediment supply regime may be dominated by geometries M and SA. However, this scale is deemed outside the scope and scale of this paper, and further stratigraphic scale (Fig. 1) analyses would be needed.

Even when all parameters are considered static, changes in sediment supply and accommodation could also be related to downstream changes in proximity from the mountain front to the basin centre, as is seen on distributive fluvial systems (DFS) (e.g. Nichols and Fisher, 2007; Weissmann et al., 2010; Weissmann et al., 2013; Owen et al., 2015a; Weissmann et al., 2015), or a combination of the two. It is infered that the presented geometries are present along a continuum, with the five geometries identified representing key transitional geometries along that continuum. Figure 12A, shows the relative percentage that each channel geometry comprises the total channel deposits at each location studied. Evidence for the geometries being along a continuum can be inferred when looking at the general trends. Geometry M and SA dominate the peripheries of the basin (proximal regions). Geometry IA can be observed in both the basin margin and basin centre and do not appear to be preferentially situated in any part of the basin. Geometry OS is dominantly found in the basin centre, and while I is present across the basin it dominates the interpreted basin centre (distal regions). Although trends are masked by inherent variability that is inevitably present when multiple systems compose a sedimentary basin fill, the general trends do suggest there is a spatial control on geometry presence from basin margin to the interpreted basin centre and therefore the geometries can be inferred to be along a continuum (Fig 12b). Further evidence for the deposits lying along a continuum can be found in Table 1 where a decrease in maximum lateral extents, storey thickness, and a change in the facies associations that dominate from geometry $\mathrm{M}$ through to I are seen. Although the maximum thickness of the channel fill bodies does generally decrease (Table 1), it is not observed in the average thickness, which may be the result of differing sized channels or systems within the basin. Evidence for the geometries being along a continuum was also found in a down depositional dip section where $\mathrm{M}$ transitions into SA. It is therefore speculated that IA represents the disarticulation of SA, with further disarticulation causing the individual storey complexes to become only partially connected in an offset manner (OS), until finally transitioning to geometry I, as is depicted in Figure 12B. A note does need to be made on the age of the deposits as the deposits become progressively younger towards the centre of the basin due to its synclinal form (Fig. 12A). Preliminary data presented in Figure 12A, does indicate that no geometry is associated with any particular age group, suggesting there is no temporal control (and therefore possible allocyclic control) on geometry formation at the channel body scale. A full temporal analyses would however need to be conducted to fully assess this, which is out of the scope of this study. It is also important to recognise that the age of the deposits at each particular location as other geometries may be found higher, or lower, in the stratigraphy at the same locations. It is emphasised here that the interpretations above are speculative and that high resolution aggradation rates and/or improved modelling efforts are required to better constrain the key controls on channel body geometries.

\section{(2) Wider applicability}

It is speculated that the geometries observed in the Bighorn Basin may be able to be observed in other sedimentary basins in which fluvial deposits reside. Figure 13 documents an example of each geometry from different formations across the globe, with geometry $\mathrm{M}$ being observed in the Altos de Pica 
Formation, Chile (Fig. 13A), geometry SA in the Sariñena Formation, Spain (Fig. 13B), geometry IA in the Morrison Formation, Colorado (Fig.13C), geometry OS also from the Sariñena Formation, Spain (Fig. 13D) and geometry I from the Chinle Formation, Utah. However, further documentation from several other basins is required before this is apparent. It is acknowledged that the facies, sediment calibre, architectural elements, or the scale of the geometries described may differ from basin to basin in relation to variation in the size of systems and source terrains. As a result facies, or quantified data in these forms, has not been included in the classification scheme (Fig. 8). A width: thickness ratio has not been added as firstly; exposures of full lateral extents and thicknesses are not commonly able to be gained in many outcrops and secondly; there is also considerable overlap between width: thickness ratios (see Table 1 and Figure 9, and Gibling, 2006), raising questions to its applicability in defining sandstone body geometry (see Bridge and Tye, 2000). Although it is not suggested that a specific size of body should be related directly to a particular sandstone geometry, it is recognised that some geometries (i.e. IA) are generally larger than others (i.e. I). It is recognised that geometry identification will be difficult in outcrops of limited lateral extent and in the subsurface. However, the geometry-based architectural scheme presented here together with the description of the internal relationship and nature of the storey surfaces along with facies descriptions may aid identification of the described geometries in poorer quality outcrops.

\section{1 (1) Conclusions}

592 This study presents the results of a basin wide architecture study of Palaeocene to Early Eocene aged

593 fluvial deposits in the Bighorn Basin, Wyoming. Key facies associations from channel and floodplain

594 environments have been described with the commonly used sheet sandstone geometry further

595 classified into 4 sub-geometries (Massive structureless channel body geometry (M), Semi-amalgamated

596 channel body geometry (SA), Internally amalgamated channel body sheet geometry (IA) and Offset

597 stacked channel body geometry (OS)) with an Isolated channel body geometry (I)) also being defined,

598 The different geometries have been defined based on external geometric form and internal

599 arrangement and nature of storey contacts. It is hypothesised that the different geometries are part of a

600 continuum of fluvial channel geometries present in the depositional record. The stacking rate and style

601 is deemed to be a key controlling factor, which is related to degree of channel migration which has been 602 speculated to be related to sediment supply and accommodation available. Two floodplain geometries

603 (sheet and ribbon) are also described. This study highlights the range of channel body architectures that 604 may be present in continental sedimentary basin fills.

\section{5 (1) Acknowledgements}

606 This work was supported by Phase 2 of the Fluvial Systems Research Group (BP, BG, Chevron, 607 ConocoPhillips, and Total). MGMS thanks the São Paulo Research Foundation (FAPESP 2014/13937-3).

608 The authors also wish to thank numerous residents of the Bighorn Basin for their kind hospitality and 609 access to land. We also thank John Howell for discussions on fluvial geometries and nomenclature, and 610 Isobel Buchanan and Alistair Swan for assistance in the field. Comments from reviewers Andrew Miall, 611 Luca Colombera and an anonymous reviewer greatly improved this manuscript.

\section{FIGURES}


613 1) Scheme of the different hierarchical scales at which fluvial architecture can be considered and how

614 they may vary in both time and space at the different scales. This study concentrates on understanding

615 the geometry of fluvial deposits at the channel body scale.

616 2) Location map of the study area. See text for references to location numbers cited.

617 3) Example images of Facies Association 1; A) Note the well-rounded nature and clast supported nature

618 of the conglomerate deposits. Note the consistent imbrication direction in rose diagram. Image taken at

619 Location 16; B) Example of horizontal stratification taken from Location 1; C) Interpreted photo showing

620 the subtle accretion surfaces and horizontal stratification found in Facies Association 1 at Location 16.

621 Note the sandstone packages are not laterally extensive and occur as small pockets within the

622 conglomerates and lack of continuity of storey surfaces.

623 4) Example images of Facies Association 2 taken from Location 27; A) Image demonstrating the poorly 624 sorted nature that is common in Facies Association 2 with large clasts lining trough sets; B) Example of 625 an immature texture from fine grained conglomerate deposits found in the facies association; C)

626 Example of accretion packages that are more commonly seen in Facies Association 2 in comparison to

627 Fig. 3. Rose diagram depicts cross-bedding direction for outcrop shown.

628 5) Example images of Facies Association 3; A) Image demonstrating the poorly sorted nature that can be 629 observed in the facies association. Note that a range of material (mudclast, nodules and pebbles) can 630 line trough sets. Pencil for scale. Picture taken from near location 25; B) Example image of heterolithic 631 accretion surfaces from Location 12. Rose diagram uses cross-bedding direction measurements note the 632 high variability; C) Example of the large scale clean cross-bedded unit from Location 7; D) Example image 633 of soft-sediment deformation commonly observed in Facies Association 3 taken from Location 22.

634 6) Example images of Facies Association 4; A) Example of the planar bedded fill within a channel deposit 635 from Location 26. Internally, beds are composed of small scale trough-cross beds, planar and ripple 636 lamination; B) Example of a mud-fill channel deposit from Location 15.

637 7) Example images of floodplain Facies association found in the Basin; A) Example of sandstone deposits 638 fond in the lacustrine facies at Location 14. Note the sharp base and lateral continuity; B) Example of a 639 lacustrine dominated section with associated coal deposits from Location 14; C) Moderate- to well640 drained palaeosol deposits intercalated with sandstone sheets. Mottling and rooting are common 641 features within this palaeosol type. Image from Location 18. D) Poorly-drained palaeosol deposits which 642 are commonly closely associated with sheet sandstone deposits from Location 6; E) Example of a splay 643 channel deposit overlying sandstone sheets within a mud-dominated succession from Location 11.

644 8) Schematic of the sandstone architectures present. Channel bodies generally decrease in thickness 645 from Geometry M through to I (see fig. 9). Geometry M, SA, IA and OS are considered to fall within the 646 sheet geometry classification, and I in the ribbon classification scheme of other authors. For geometric 647 dimension ranges of the channel bodies and storey surfaces see Table 1. Key characteristics are noted 648 next to each geometry defined. See text for discussion on how the different geometries have been 649 defined.

650 9) Graph showing the distribution of measured thicknesses for each geometry described (see text for 651 description of the different geometries). Box and whisker plots show the range, $1^{\text {st }}$ and $3^{\text {rd }}$ quartiles, and 
the median for each geometry. Coloured stars denote the average thickness for each geometry. $\mathrm{N}=184$ for whole dataset.

10) Example images of geometries $M, S A$ and $I A ; A$ ) Example image of a portion of geometry $M$ from Location 16. Note the lateral discontinuity of storey surface and extent of the channel body; B) Example images of geometry SA with interpretation from Location 27. Note the floodplain intercalation that separates the channel deposits which are laterally amalgamated; C) Image of an outcrop dominated by geometry IA from Location 22; D) Close up example of geometry IA from Location 12 highlighting the internal complexities and multistorey nature of the deposits.

11) Example images of geometries OS and I; A) Image from Location 25 showing the offset nature of storey packages in geometry OS. Note the body is single storey in some places, yet multistorey in others; B) Large scale view of a series of OS deposits from Location 25, note that they appear to have a broad sheet like appearance; C) Example image of geometry I from Location 24.

12) A) Map showing the spatial distribution of the described geometries across the basin. Pie charts depict the proportion of channels for each geometry from each sedimentary log taken. Ages taken from Gingerich and Clyde (2001). B) Schematic demonstrating the transitional nature of the geometries from geometry $\mathrm{M}$ through to $\mathrm{I}$. Palaeocurrent direction is inferred to be from the top-left to bottom-right in the schematic and does not relate to any specific area of the Bighorn Basin.

Figure 13) Examples of the described geometries in other sedimentary basins. A) Geometry $M$ in the Altos de Pica Formation, Chile B) Geometry SA in the Sariñena Formation, Spain C) Geometry IA in the Morrison Formation, USA D) Geometry OS from the Sariñena Formation, Spain E) geometry I from the Chinle Formation, Utah.

\section{TABLES}

Table 1 - Summary data for each geometry defined within this study. See text for facies association descriptions. Brackets indicate the average for each category. Storey thickness are preserved thickness.

\section{References}

Abdul, A.H., Hilgen, F.J., van Luijk, G.M., Sluijs, A., Kraus, M.J., Pares, J.M., and Gingerich, P.D., (2008), Astronomical climate control on paleosol stacking patterns in the upper Paleocene-lower Eocene Willwood Formation, Bighorn Basin, Wyoming. Geology, 36, 531-534.

Abels, H.A., Kraus, M.J., and Gingerich, P.D., (2013) Precession-scale cyclicity in the fluvial lower Eocene Willwood Formation of the Bighorn Basin, Wyoming (USA). Sedimentology, 60, 1467-1483.

Allen, J.R.L., (1978) Studies in fluviatile sedimentation: an exploratory quantitative model for the architecture of avulsion-controlled alluvial suites. Sedimentary Geology, 21, 129-147.

Allen, J.R.L., (1983) Studies in fluviatile sedimentation: Bars, bar-complexes and sandstone sheets (lowsinuoisty braided streams) in the Brownstones (L.Devonian) Welsh Borders. Sedimentary Geology, 33, 237-293.

Banham, S.G., and Mountney, N.P., (2013) Controls on fluvial sedimentary architecture and sedimentfill state in salt-walled mini-basins: Triassic Moenkopi Formation, Salt Anticline Region, SE Utah, USA. Basin Research, 25, 1-29. 
Blakey, R.C., and Gubitosa, R., (1984) Controls of sandstone body geometry and architecture in the Chinle Formation (Upper Triassic), Colorado Plateau. Sedimentary Geology, 38, 51-86.

Bown, T.M., and Kraus, M.J., (1987) Integration of channel and floodplain suites, developmental sequence and lateral relations of alluvial paleosols. Journal of Sedimentary Petrology, 57, 587-601.

Bown, T.M., and Kraus, M.J., (1981) Lower Eocene alluvial paleosols (Willwood Formation, northwest Wyoming, U.S.A) and their significance for paleoecology, paleoclimatology, and basin analyses. Palaeogeography, Palaeoclimatology, Palaeoecology, 34, 1-30.

Bridge, J.S., (1993), Description and interpretation of fluvial deposits: a critical perspective. Sedimentology, 40, 801-810.

Bridge, J.S., (2008) Numerical modelling of alluvial deposits: recent developments. In: Analogue and numerical modelling of sedimentary systems: from understanding to prediction. Special Publication Number 40 of the IAS, (Eds De Boer, P., Postma, G., van der Zwan, K., Burgess, P., and Kukla, P.) 97-138.

Bridge, J.S., and Leeder, M.R., (1979) A simulation model of alluvial stratigraphy. Sedimentology, 26, 617-644.

Bridge, J.S., and Tye, R.S., (2000) Interpreting the dimensions of ancient fluvial channel bars, channels, and channel belts from wireline-logs and cores. AAPG Bulletin , 84, 1205-1228.

Bristow, C.S., and Best, J.L., (1993) Braided rivers: perspectives and problems. Geological Society, London, Special Publications, 75, 1-11.

Cain, S.A., and Mountney, N.P., (2009) Spatial and temporal evolution of a terminal fluvial fan system: the Permian Organ Rock Formation, South-east Utah, USA. Sedimentology, 56, 1774-1800.

Cecil, B.C., (2003) The concept of autocyclic and allocyclic controls on sedimentation and stratigraphy, emphasizing the climatic variables. In: Climate controls on stratigraphy. SEPM Special Pbulication Numer 77. (Eds Cecil, B. C. and Edgar, T.N.) 13-20.

Cecil, B.C., (2013) An overview and interpretation of autocyclic and allocyclic processes and the accumulation of strata during the Pennsylvanian-Permian transition in the central Appalachian Basin, USA. International Journal of Coal Geology, 119, 21-31.

Collinson, J.D., (1996) Alluvial sediments. In: Sedimentary environments and facies (Ed Reading, H.G.) 37-82.

Corbeanu, R.M., Soegaard, K., Szerbiak, R.B., Thurmond, J.B., Mcmechan, G.A., Wang, D., Snelgrove, S., Forster, C.B., Menitove, A., and Corbeanu, R.M., (2001) Detailed internal architecture of a fluvial channel sandstone determined from outcrop, cores, and 3-D ground-penetrating radar: Example from the middle Cretaceous Ferron Sandstone, east-central Utah. AAPG Bulletin, 9, 15831608.

Davies-Vollum, K.S., and Kraus, M.J., (2001) A relationship between alluvial backswamps and avulsion cycles: an example from the Willwood Formation of the Bighorn Basin, Wyoming. Sedimentary Geology, 140, 235-249.

Davies-vollum, K.S., and Wing, S.L., (1998) Taphononic, and climatic aspects of Eocene swamp deposits (Willwood Formation, Bighorn Basin , Wyoming). PALAIOS, 13, 28-40. 
Decelles, P.G., (2004) Late Jurassic to Eocene evolution of the Cordilleran thrust belt and foreland basin system, western U.S.A. American JournaL of Science, 304, 105-168.

DeCelles, P.G., Gray, M.B., Ridgway, K.D., Cole, R.B., Pivnik, D.A., Pequera, N., and Srivastava, P., (1991) Controls on synorogenic alluvial-fan architecture, Beartooth Conglomerate (Palaeocene), Wyoming and Montana. Sedimentology, 38, 567-590.

Dickinson, W.R., Klute, M.A., Hayes, M.J., Janecke, S.U., Erik, R., Mckittrick, M.A., Olivares, M.D., Klute, M.A., and Hayes, M.J., (1988) Paleogeographic and paleotectonic setting of Laramide sedimentary basins in the central Rocky Mountain region. Geological Society of America Bulletin, 100.

Fisher, J. A., Nichols, G.J., and Waltham, D. A., (2007) Unconfined flow deposits in distal sectors of fluvial distributary systems: Examples from the Miocene Luna and Huesca Systems, northern Spain. Sedimentary Geology, 195, 55-73.

Foreman, B.Z., (2014) Climate-driven generation of a fluvial sheet sand body at the Paleocene-Eocene boundary in north-west Wyoming (USA). Basin Research, 26, 225-241.

Friend, P.F., (1983) Towards the field classification of alluvial architecture or sequence. In: Modern and ancient fluvial systems: International Association of Sedimentologists, Special Publication 6 (Eds Collinson, J.D. and Lewin, J), 345-354.

Friend, P.F., Slater, M.J., and Williams, R.C., (1979) Vertical and lateral building of river sandstone bodies, Ebro Basin, Spain. Journal of the Geological Society, 136, 39-46.

Gibling, M.R., (2006) Width and thickness of fluvial channel Bodies and valley fills in the geological record: A literature compilation and classification. Journal of Sedimentary Research, 76, 731-770.

Gingerich, P.D., (1983) Paleocene-Eocene faunal zones and a preliminary analysis of Laramide structural deformation in the Clark's Fork Basin, Wyoming. In: 34th Annual Field conference, Wyoming Geological Association Guidebook, 185-195.

Gingerich, P.D., (2003) Mammalian responses to climate change at the Paleocene-Eocene boundary: Polecat Bench record in the northern Bighorn Basin, Wyoming. Geological Society of America Special Papers, 369, 463-478.

Gingerich, P.D. and Clyde, W.C., (2001) Overview of mammalian biostratigraphy in the PaleoceneEocene Fort Union and Willwood Formations of the Bighorn and Clarks Fork Basins. University of Michigan papers on paleontology, 33, 1-14.

Gulliford, A.R., Flint, S.S., and Hodgson, D.M., (2014) Testing Applicability of Models Of Distributive Fluvial Systems Or Trunk Rivers In Ephemeral Systems: Reconstructing 3-D Fluvial Architecture In the Beaufort Group, South Africa. Journal of Sedimentary Research, 84, 1147-1169.

Hickey, L.J., and Yuretich, R., (1997) The Belfry Member of the Fort Union Formation, an allocyclic lacustrine deposit of middle Paleocene agin in the Bighorn Basin, Montana and Wyoming. In: Bighorn Basin: 50 years on the Frontier: Evolution of the geology of the Bighorn Basin: Fieldtrip Symposium, 38-42.

Hirst, J.P.P., (1991) Variations in alluvial architecture across the Oligo-Miocene Huesca fluvial system, Ebro Basin, Spain. In: The three dimensional facies architecture of terrigenous clastic sediments and its implications for hydrocarbon discovery and recovery. Concepts in Sedimentology and 
Paleontology (Eds: Miall, A.D. and Tyler, N.), 111-121.

Hornung, J., and Aigner, T., (1999) Reservoir and aquifer characterization of fluvial architectural elements: Stubensandstein, Upper Triassic, southwest Germany. Sedimentary Geology, 129, 215280.

Huerta, P., Armenteros, I., and Silva, P.G., (2011) Large-scale architecture in non-marine basins: the response to the interplay between accommodation space and sediment supply, Sedimentology, 58, $1716-1736$.

Jackson, R.G., (1975) Hierarchical attributes and a unifying model of bed forms composed of cohesionless material and produced by shearing flow. Bulletin of the Geological Society of America, 86, 1523-1533.

Jones, H.L., and Hajek, E.A., (2007) Characterizing avulsion stratigraphy in ancient alluvial deposits. Sedimentary Geology, 202, 124-137.

Kennett, J.P., and Stott, L.D., (1991) Abrupt deep-sea warming, paleoceanographic changes and benthic extinctions at the end of the Palaeocene. Nature, 353, 225-228.

Kraus, M.J., (1980) Genesis of a fluvial sheet sandstone, Willwood Formation, northwest Wyoming. University of Michigan Papers on Paleontology, 24, 87-94.

Kraus, M.J., (1985) Early Tertiary quartzite conglomerates of the Bighorn Basin and their significance for paleogeographic reconstruction of northwest Wyoming. In: Cenozoic Paleogeography of Westcentral United States, Rocky Mountain Section of the SEPM (Eds: Flores, R.M. and Kaplan, S.S.), 7191.

Kraus, M.J., (1987) Integration of channel and floodplain suites, II Vertical relations of alluvial paleosols. Journal of Sedimentary Petrology, 57, 602-612.

Kraus, M.J., (1996) Avulsion deposits in Lower Eocene alluvial rocks, Bighorn Basin, Wyoming. Journal of Sedimentary Research, 66, 354-363.

Kraus, M.J., (1999) Paleosols in clastic sedimentary rocks: their geologic applications. Earth-Science Reviews, 47, 41-70.

Kraus, M.J., (2001) Sedimentology and depositional setting of the Willwood Formation in the Bighorn and Clarks Fork Basins In: Paleocene-Eocene Stratigraphy and Biotic change in the Bighorn and Clarks Fork Basins, Wyoming, University of Michigan Papers Paleontology, No 33 (Ed: Gingerich, P.D.), 15-28.

Kraus, M.J., and Bown, T.M., (1993) Palaeosols and sandbody prediction in alluvial sequences. Geological Society, London, Special Publications, 73, 23-31.

Kraus, M.J., and Gwinn, B., (1997) Facies and facies architecture of Paleogene floodplain deposits, Willwood Formation, Bighorn Basin, Wyoming, USA. Sedimentary Geology, 114, 33-54.

Kraus, M.J., and Wells, T.M., (1999) Recognizing avulsion deposits in the ancient stratigraphical record. In: Fluvial Sedimentology 6. Special publication of the International Association of Sedimentologists (Eds: Smith, N.D. and Rogers, J.), 251-268.

Kraus, M.J., and Davies-Vollum, K.S., (2004) Mudrock-dominated fills formed in avulsion splay channels: Examples from the Willwood Formation, Wyoming. Sedimentology, 51, 1127-1144. 
808

809

810

811

812

813

814

815

816

817

818

819

820

821

822

823

824

825

826

827

828

829

830

831

832

833

834

835

836

837

838

839

840

841

842

843

844

845

846

Kraus, M.J., and Hasiotis, S.T., (2006) Significance of Different Modes of Rhizolith Preservation to Interpreting Paleoenvironmental and Paleohydrologic Settings: Examples from Paleogene Paleosols, Bighorn Basin, Wyoming, U.S.A. Journal of Sedimentary Research, 76, 633-646.

Kraus, M.J., and Riggins, S., (2007) Transient drying during the Paleocene-Eocene Thermal Maximum (PETM): Analysis of paleosols in the bighorn basin, Wyoming: Palaeogeography, Palaeoclimatology, Palaeoecology, 245, 444-461.

Kraus, M.J., Mclnerney, F.A., Wing, S.L., Secord, R., Baczynski, A.A., and Bloch, J.I., (2013) Paleohydrologic response to continental warming during the Paleocene-Eocene Thermal Maximum, Bighorn Basin, Wyoming. Palaeogeography, Palaeoclimatology, Palaeoecology, 370, 196-208.

Kraus, M.J., Woody, D.T., Smith, J.J., and Dukic, V., (2015) Alluvial response to the Paleocene-Eocene Thermal Maximum climatic event, Polecat Bench, Wyoming (U.S.A.). Palaeogeography, Palaeoclimatology, Palaeoecology, 435, 177-192.

Leeder, M.R., (1978) A quantitative stratigraphoc model for alluviam with special reference to channel deposit density and interconnectedness. Canadian Society of Petroleum Geologist Memoir 5, 587596.

Leleu, S., Hartley, A.J., and Williams, B.P.J., (2009) Large-Scale Alluvial Architecture and Correlation in a Triassic Pebbly Braided River System, Lower Wolfville Formation (Fundy Basin, Nova Scotia, Canada). Journal of Sedimentary Research, 79, 265-286.

Lillegraven, J.A., (2009) Where was the western margin of northwestern Wyoming's Bighorn Basin late in the early Eocene? Papers on Geology, Vertebrate Paleontology, and Biostratigraphy in Honor of Michael O. Woodburne, 65, 37-81.

Miall, A.D., (1985) Architectural-element analysis: A new method of facies analysis applied to fluvial deposits. Earth-Science Reviews, 22, 261-308.

Miall, A.D., (1988) Architectural elements and bounding surfaces in fluvial deposits: Anatomy of the Kayenta Formation (Lower Jurassic), Southwest Colorado. Sedimentary Geology, 55, 233-262.

Miall, A.D., (1994) Reconstructing fluvial macroform architecture from two-dimensional outcrops: examples from the Castlegate Sandstone, Book Cliffs, Utah. Journal of Sedimentary Research, 64, 146-158.

Miall, A.D., (1996) The Geology of Fluvial deposts: Sedimentary facies, basin analysis, and petroleum geology. Springer-verlag, New York, 582.

Miall, A.D., (2016) The valuatin of unconformities. Earth-science Reviews, 163, 22-71.

Neasham, J.W., and Vondra, C.F., (1972) Stratigraphy and petrology of the Lower Eocene Willwood Formation, Bighorn Basin, Wyoming. Geological Society of America Bulletin, 83, 2167-2180.

Nichols, G.J., and Fisher, J.A., (2007) Processes, facies and architecture of fluvial distributary system deposits. Sedimentary Geology, 195, 75-90.

Owen, A., Nichols, G.J., Hartley, A.J., Weissmann, G.S., and Scuderi, L.A., (2015a) Quantification of a distributive fluvial system: The Salt Wash DFS of the Morrison Formation, SW USA. Journal of Sedimentary Research, 85, 544-561. 
Owen, A., Nichols, G.J., Hartley, A.J., and Weissmann, G.S., (2015b) Vertical trends within the prograding Salt Wash distributive fluvial systems, SW United States. Basin Research, 1-17.

Potter, P., (1967) Sand Bodies and Sedimentary Environments: A Review. AAPG Bulletin, 3, 337-365.

Pranter, M.J., and Sommer, N.K., (2011) Static connectivity of fluvial sandstones in a lower coastal-plain setting: An example from the Upper Cretaceous lower Williams Fork Formation, Piceance Basin, Colorado. AAPG Bulletin, 95, 899-923.

Ramos, A., and Sopena, A., (1983) Gravel bars in low-sinuosity streams (Permian and Triassic, central Spain). In: Modern and Ancient Fluvial Systems: International Association of Sedimentologists, Special Publication 6 (Eds: Collinson, J.D. and Lewin, J), 301-312.

Retallack, G.J., (2001) Soils of the past. An introduction to paleopedology: Blackwell Science, 520.

Rouse, J.T., (1937) Genesis and structural relationships of the Absaroka volcanic rocks, Wyoming. Bulletin of the Geological Society of America, 48, 1257-1296.

Rust, B.R., (1972) Structure and process in a braided river. Sedimentology, 18, 221-245.

Seeland, D., (1998) Late Cretaceou , Paleocene, and Early Eocene Paleogeography of the Bighorn Basin and Northwestern Wyoming. In: Cretaceous and Lower tertiary Rocks of the Bighorn Basin, Wyoming and Montana; 49th Annual Field Conference Guidebook, 1-29.

Shen, Z., Törnqvist, T.E., Mauz, B., Chamberlain, E.L., Nijhuis, A.G., and Sandoval, L., (2015) Episodic overbank deposition as a dominant mechanism of floodplain and delta-plain aggradation. Geology, 43, 10, 875-878.

Singh, H., Parkash, B., and Gohain, K., (1993) Facies analysis of the Kosi megafan deposits. Sedimentary Geology, 85, 87-113.

Snyder, W.S., Dickinson, W.R., and Silberman, M.L., (1976) Tectonic implications of space-time patterns of Cenozoic magmatism in the Western United States. Earth and Planetary Science Letters, 32, 91106.

Sundell, K.A., (1990) Sedimentation and tectonics of the Absaroka Basin of northwestern wyoming. In: Wyoming sedimentation and Tectonics, 41st Annial Field Conference Guidebook, 105-122.

Weissmann, G.S., Hartley, A.J., Nichols, G.J., Scuderi, L.A., Olson, M.E., Buehler, H., and Banteah, R., (2010) Fluvial form in modern continental sedimentary basins: Distributive fluvial systems. Geology, 38, 39-42.

Weissmann, G.S., Hartley, A.J., Scuderi, L.A., Nichols, G.J., Davidson, S.K., Owen, A., Atchley, S.C., Bhattacharyya, P., Ghosh, P., Nordt, L.C., Michel, L., and Tabor, N.J., (2013) Prograding distributive fluvial systems - geomorphic models and ancient examples. In: New Frontiers in Paleopedology and Terrestrial paleoclimatology. SEPM Special Number 104 (Eds: Dreise, S.G., Nordt, L.C., and McCarthy, P.L.), 131-147.

Weissmann, G.S., Hartley, A.J., Scuderi, L.A., Nichols, G.J., Owen, A., Wright, S., Felicia, A.L., Holland, F., and Anaya, F.M.L., (2015) Fluvial geomorphic elements in modern sedimentary basins and their potential preservation in the rock record: A review. Geomorphology, 250, 187-219.

Willis, B.J., and Behrensmeyer, A. K., (1995) Fluvial systems in the Siwalik Miocene and Wyoming Paleogene. Palaeogeography, Palaeoclimatology, Palaeoecology, 115, 13-35. 


\begin{tabular}{|c|c|c|c|c|c|}
\hline Geometry & $\begin{array}{c}\text { Facies } \\
\text { associations } \\
\text { present }\end{array}$ & $\begin{array}{c}\text { Maximum } \\
\text { measured } \\
\text { lateral extent } \\
(\mathrm{Km})\end{array}$ & $\begin{array}{c}\text { Thickness of } \\
\text { channel fill } \\
\text { body }(\mathrm{m})\end{array}$ & $\begin{array}{c}\text { Storey } \\
\text { thickness (m) }\end{array}$ & $\begin{array}{c}\text { Number of } \\
\text { storeys (m) }\end{array}$ \\
\hline M & 1,2 & 5.5 & $\begin{array}{c}5.7-47.5 \\
(21.4)\end{array}$ & $\begin{array}{c}1.4-47.5 \\
(10.1)\end{array}$ & Up to 5 \\
& $1,2,3$ & 3.5 & $1-44.5$ & $1-30.3$ & Up to 3 \\
\hline SA & $2,3,4$ & 3 & $4.1-27.6$ & $1.5-14.3$ & Up to 4 \\
& & & $(11.0)$ & $(4.6)$ & $(2.4)$ \\
\hline IA & 3,4 & 1 & $2.4-13.7$ & $0.3-7.1$ & Up to 3 \\
\hline OS & 3,4 & 1 & $(7.7)$ & $(3.8)$ & $(2)$ \\
\hline I & & & $(4.2)$ & N/A & N/A \\
\hline
\end{tabular}

Wilson, A., Flint, S., Payenberg, T., Tohver, E., and Lanci, L., (2014) Architectural Styles and Sedimentology of the Fluvial Lower Beaufort Group, Karoo Basin, South Africa. Journal of Sedimentary Research, 84, 326-348.

Wing, S.L., and Currano, E.D., (2013) Plant response to a global greenhouse event 56 million years ago. American Journal of Botany, 100, 1234-54.

Wing, S.L., Harrington, G.J., Smith, F.A., Bloch, J.I., Boyer, D.M., and Freeman, K.H., (2005) Transient floral change and rapid global warming at the Paleocene-Eocene boundary. Science, 310, 993-996.

Yuretich, R.F., Hickey, L.J., Gregson, B.P., and Hsia, Y.L., (1984) Lacustrine deposits in the Paleocene Fort Union Formation, northern Bighorn Basin, Montana. Journal of Sedimentary Petrology, 54, 836-852. 
Bedforms - ripples/dunes

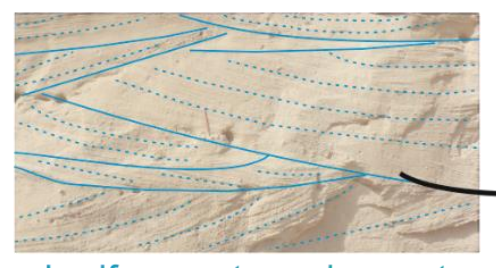

bedform sets and co-sets

\section{Barform and storey}

- lateral/downstream accreting

- incision of active channel into previous

deposits

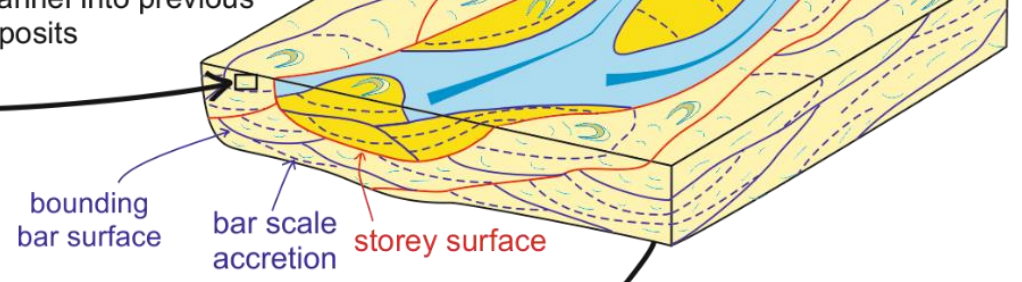

Channel body-single/multiple channel fills encased within floodplain material

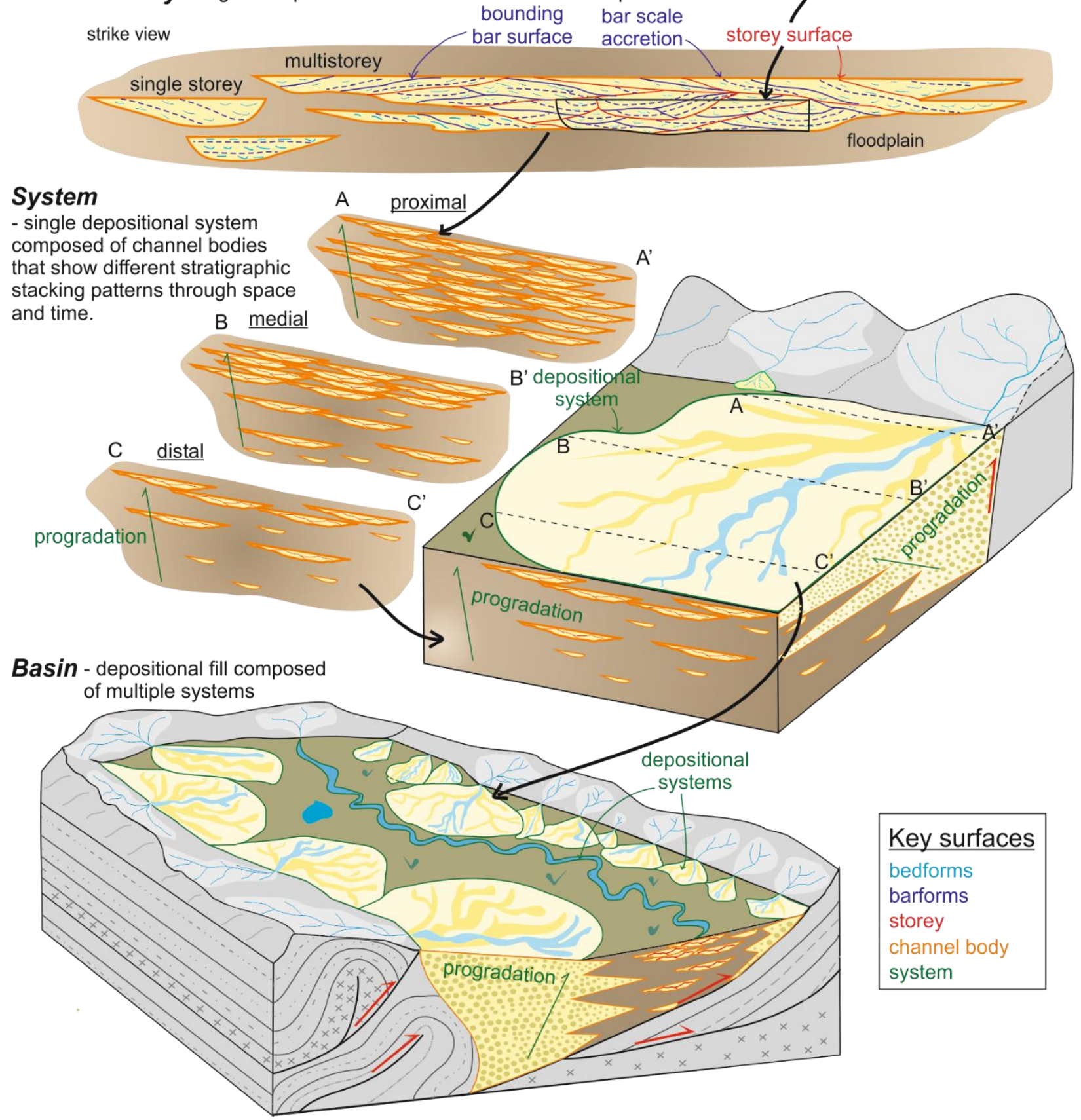



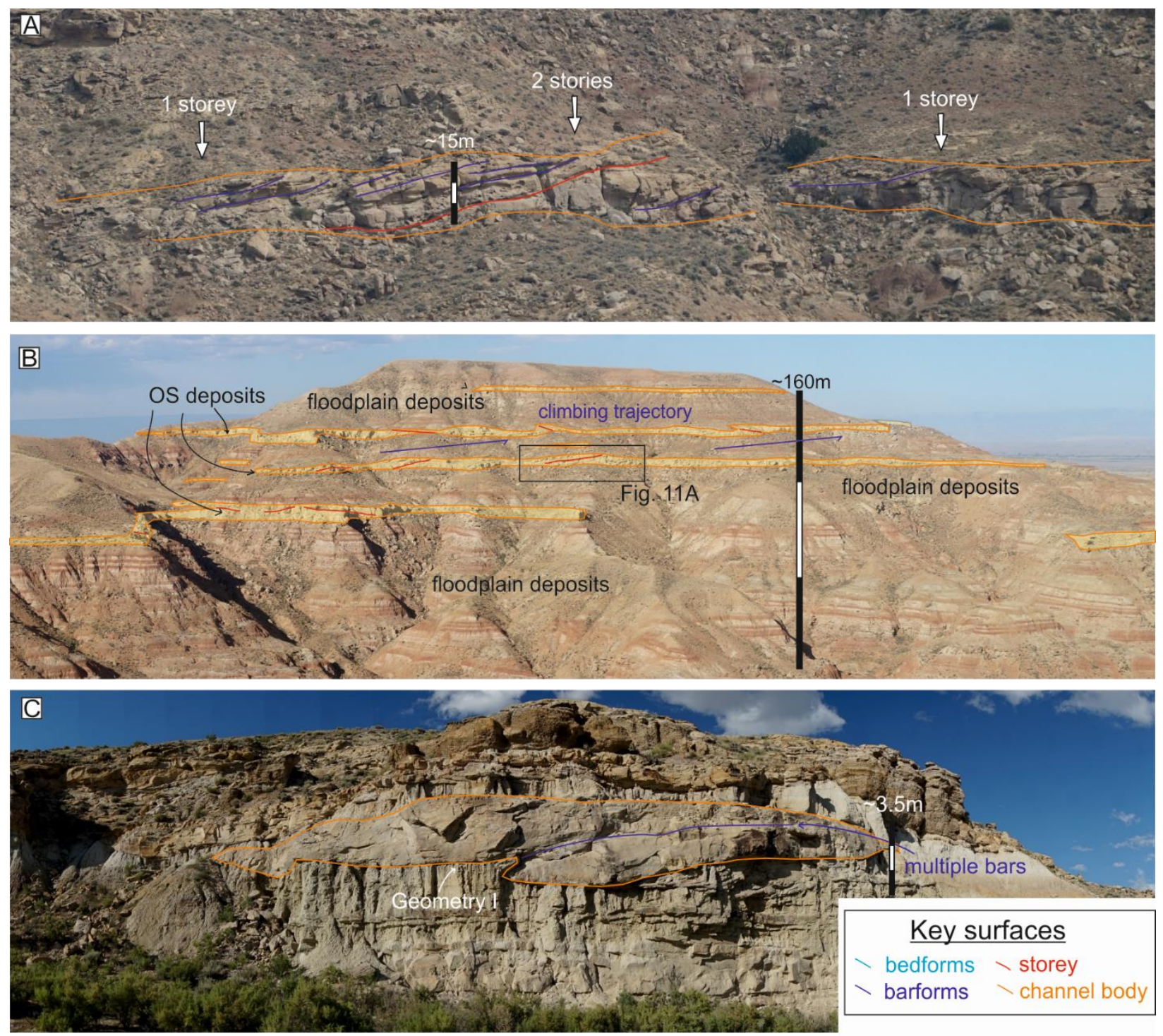
A
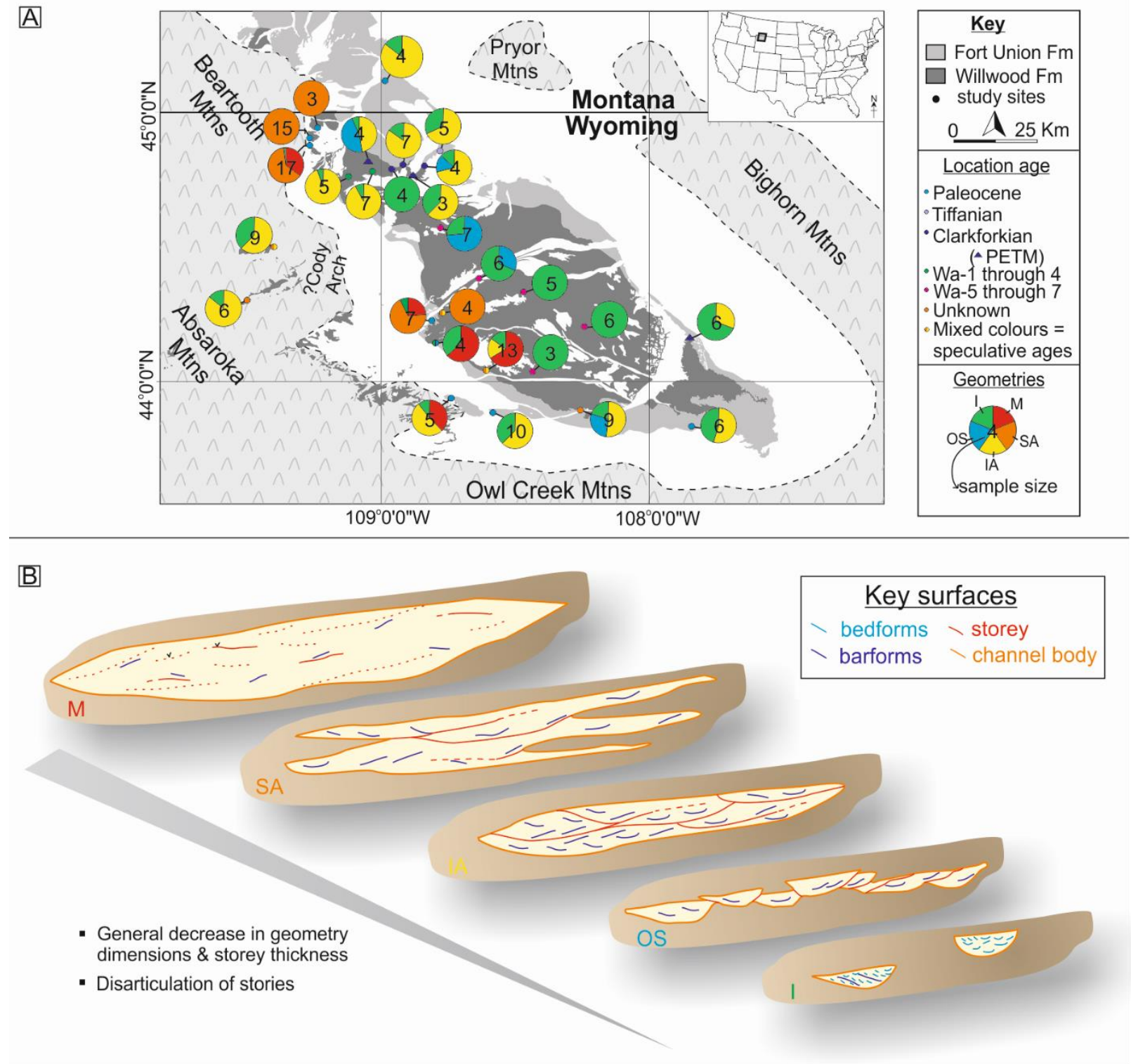

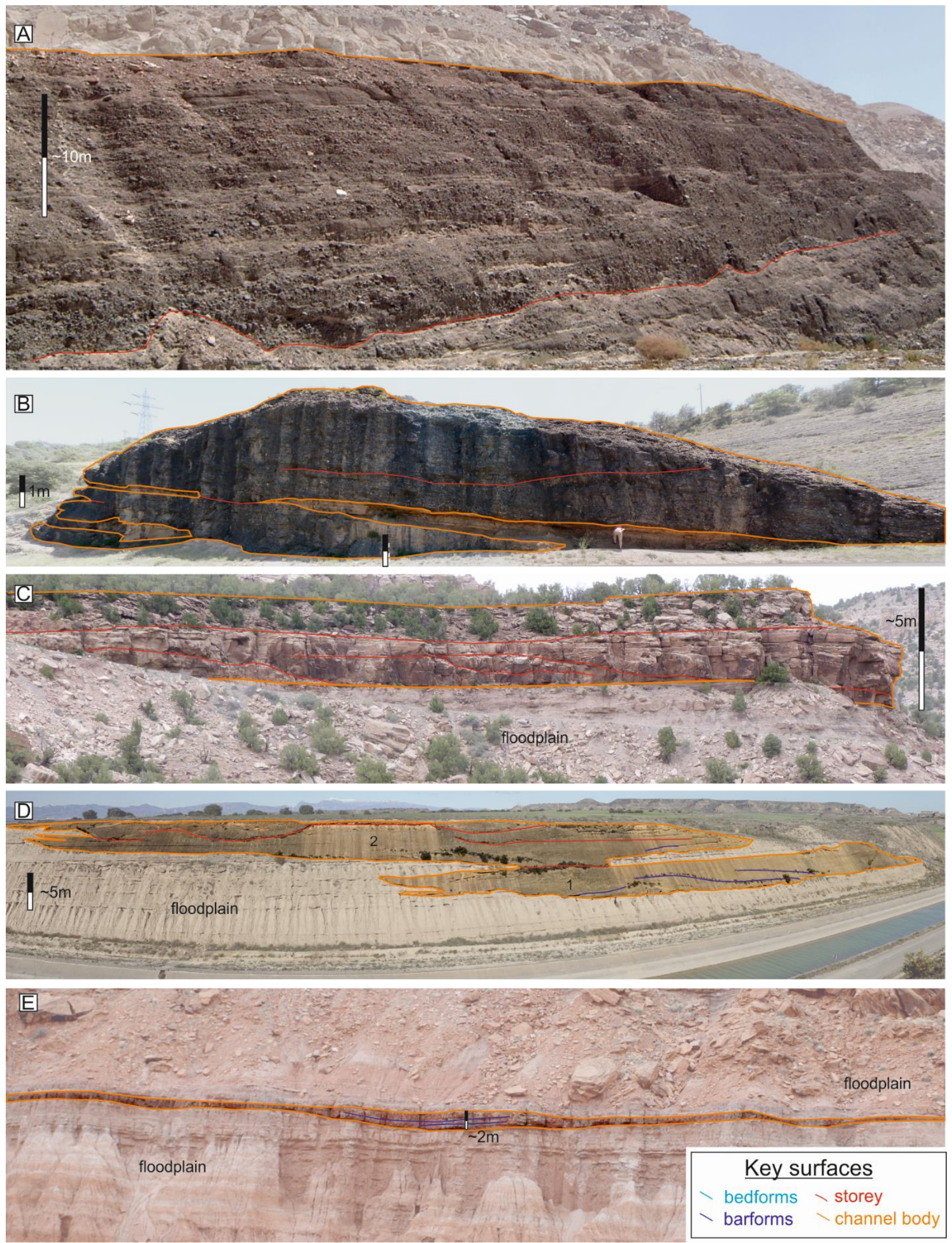